\title{
Mechanical thrombectomy for reperfusion of acute ischemic stroke in a Stroke Unit in Argentina
}

\author{
Trombectomía mecánica para la reperfusión en el accidente cerebrovascular agudo en \\ una Unidad Cerebrovascular de Argentina
}

Matias ALET', Federico Rodriguez LUCCl', Sebastián AMERISO'

\begin{abstract}
Stroke is an important cause of morbidity and mortality worldwide. Reperfusion therapy with intravenous tissue plasminogen activator (IVtPA) was first implemented in 1996. More recently, endovascular reperfusion with mechanical thrombectomy (MT) demonstrated a robust beneficial effect, extending the $4.5 \mathrm{~h}$ time window. In our country, there are difficulties to achieve the implementation of both procedures. Objective: Our purpose is to report the early experience of a Comprehensive Stroke Center in the use of MT for acute stroke. Methods: Analysis of consecutive patients from January 2015 to September 2018, who received reperfusion treatment with MT. Demographic data, treatment times, previous use of IV-tPA, site of obstruction, recanalization, outcomes and disability after stroke were assessed. Results: We admitted 891 patients with acute ischemic stroke during this period. Ninety-seven received IV-tPA (11\%) and 27 were treated with MT (3\%). In the MT group, mean age was 66.0 14.5 years. Median NIHSS before MT was 20 (range:14-24). The most prevalent etiology was cardioembolic stroke (52\%). Prior to MT, 16 of 27 patients (59\%) received IV-tPA. Previous tPA treatment did not affect onset to recanalization time or door-to-puncture time. For MT, door-to-puncture time was $104 \pm 50$ minutes and onset to recanalization was $289 \pm 153$ minutes. Successful recanalization ( $\mathrm{mTICI}$ grade $2 \mathrm{~b} / 3$ ) was achieved in 21 patients (78\%). At three-month follow-up, the median NIHSS was 5 (range:4-15) and mRS was $0-2$ in 37\%, and $\geq 3$ in 63\%. Conclusions: With adequate logistics and strict selection criteria, MT can be implemented in our population with results like those reported in large clinical trials.
\end{abstract}

Keywords: acute stroke; Argentina; mechanical thrombectomy; systemic thrombolysis.

\section{RESUMEN}

El accidente cerebrovascular isquémico (ACVi) es una importante causa de morbi-mortalidad a nivel mundial. La reperfusión con trombólisis endovenosa es utilizada desde 1996. Más recientemente, la reperfusión con trombectomía mecánica (TM) ha demostrado un beneficio consistente extendiendo la ventana terapéutica. En nuestro país existen dificultades para que su implementación sea una práctica habitual. Objetivo: Reportamos la experiencia de un Centro Integral de Neurología Vascular en el uso de TM como tratamiento del ACVi agudo. Métodos: Análisis retrospectivo de pacientes consecutivos desde enero 2015 a septiembre 2018, que recibieron reperfusión con TM. Se registraron datos demográficos, tiempos de tratamiento, uso de rtPA, sitio de obstrucción, recanalización, severidad del evento y discapacidad. Resultados: Se evaluaron 891 pacientes con ACVi en este periodo. 97 recibieron rtPA (11\%) y 27 recibieron TM (3\%). En el grupo TM, la edad promedio fue 66 años ( $₫ 14.5)$. Mediana de NIHSS previo a TM: 20 (RIC 14-24). La etiología más frecuente fue cardioembolia (52\%). Previo a TM, 16 pacientes (59\%) recibieron rtPA endovenoso. No hallamos efecto del rtPA en tiempo de recanalización por TM o tiempo puerta-punción. Para la TM, el tiempo puerta-punción fue $104 \pm 50$ minutos y el tiempo entre inicio de síntomas-recanalización fue 289 153 minutos. En 21 pacientes (78\%) se logró recanalización exitosa ( $\mathrm{TICl}$ 2B/3). En el seguimiento a tres meses, el mRS fue 0-2 en el $37 \%$ y $\geq 3$ en el 63\%. Conclusión: Una logística adecuada y un estricto criterio de selección ha posibilitado el uso de TM en nuestra población, obteniendo resultados similares a aquellos reportados en los estudios clínicos publicados.

Palabras clave: accidente cerebrovascular; Argentina; trombectomía mecánica; trombólisis endovenosa.

Stroke is an important cause of morbidity and mortality worldwide and in Argentina ${ }^{1-4}$. Since 1996, intravenous reperfusion treatment with tissue plasminogen activator (IV-tPA) is available and proved to reduce disability with a therapeutic window up to 4.5 hours from symptoms onset ${ }^{5}$. The publication of several clinical trials demonstrated a robust benefit of endovascular mechanical thrombectomy (MT) with a window of 6 to 12 hours (according to the inclusion criteria of each study), in patients with proximal arterial obstructions of the anterior cerebral circulation ${ }^{6-10}$. 
Recently, the DAWN trial demonstrated the clinical efficacy of MT in proximal occlusions in highly selected patients, with stroke occurring between 6 and 24 hours after the onset of symptoms ${ }^{11}$. These benefits were confirmed by DEFUSE III trial, which included patients with NIHSS $\geq 6$ and treatment 6 to 16 hours after symptoms onset ${ }^{12}$.

In our country, MT for acute stroke is being used in a few selected centers, and there are difficulties to achieve the adequate implementation of acute stroke treatment programs throughout most of the country.

We report the initial experience of a Comprehensive Stroke Center in the use of MT as a reperfusion treatment for acute ischemic stroke.

\section{METHODS}

We assessed consecutive patients with ischemic stroke who received reperfusion treatment with MT in our center, between January 2015 and September 2018. We assessed demographic data, vascular risk factors, time elapsed between the onset of symptoms and of MT, use of IV-tPA prior to MT, severity of stroke measured through the National Institute of Health Stroke Scale (NIHSS) ${ }^{13}$ prior to MT, site of obstruction, symptoms to puncture time and door to puncture time. The degree of recanalization was measured using the modified Thrombolysis in Cerebral Infarction scale (mTICI), and successful recanalization was defined as grade $2 b$ (i.e., antegrade reperfusion of more than half of the previously occluded target artery ischemic territory) or grade 3 (complete antegrade reperfusion $)^{14}$. The evolution was evaluated through the NIHSS scale at three months and the degree of disability measured by the Modified Rankin Scale (mRS) at 90 days. The presence of a $\mathrm{mRS} \leq 2$ was considered a good outcome.

Every patient underwent cerebral tomography (CT) and/ or magnetic resonance image (MRI) of the brain at the time of admission, followed by a vascular imaging to define the precise site of obstruction. Depending on the availability and/or characteristics of the patient, control brain CT or MRI were performed 24 hours after the procedure.

\section{Treatment protocol}

All patients were treated according to a standardized protocol for acute ischemic stroke in our center. For those cases eligible for performing intravenous thrombolysis, IV-tPA was administered, and if occlusion of an intracranial artery (internal carotid, proximal middle cerebral artery -M1 or M2-, proximal anterior cerebral artery, proximal posterior cerebral artery or basilar artery) was present, we considered MT following IV-tPA. For those patients who were not candidates for IV-tPA (time window after 4.5 hours or contraindications to IV-tPA), MT was directly implemented.

Selection criteria for MT were occlusion of an intracranial artery; age $\geq 18$ years; NIHSS score $\geq 6$; and treatment feasible to be initiated (groin puncture) within 6 hours of symptom onset. MT was performed with Stent Retriever Solitaire ${ }^{\text {ix }}$ or Trevo ${ }^{\mathrm{ns}}$.

\section{Data analysis}

Categorical variables are presented as numbers or percentages. Quantitative variables are expressed as means and standard deviations (SD), or medians and interquartile ranges (IQR), according to their distribution. Parametric and nonparametric tests were used, as appropriate. In the comparative evaluation of proximal and distal occlusions, the means of the nonparametric variables were analyzed with Fisher's test. The differences were considered significant for $\mathrm{p}<0.05$ values.

The statistical analysis was performed with the SPSS software, version 20.0 (IBM Corp., Armonk, NY).

\section{RESULTS}

Overall, 891 patients were admitted with a diagnosis of acute ischemic stroke from January 2015 to September 2018. IV-tPA was administered to 97 patients (11\%), while 27 patients $(3 \%)$ were treated with MT according to predetermined selection criteria. Table 1 summarizes the demographic, clinical and imaging characteristics of MT cases.

Table 1. Clinical and demographic characteristics of mechanical thrombectomy cases $(n=27)$.

\begin{tabular}{|cc|}
\hline Age, mean $( \pm S D)$ & $66( \pm 14.5)$ \\
\hline Male, $\mathrm{n}(\%)$ & $15(56)$ \\
\hline NIHSS on admission, median $(\mathrm{IQR})$ & $20(14,24)$ \\
\hline Vascular risk factors, $\mathrm{n}(\%)$ & $15(56)$ \\
\hline Hypertension & $11(41)$ \\
\hline Dyslipidemia & $2(7)$ \\
\hline Current smoker & $12(44)$ \\
\hline Former smoker & $10(37)$ \\
\hline Atrial fibrillation & $1(4)$ \\
\hline Chronic renal failure & $10(37)$ \\
\hline Previous stroke / TIA & \\
\hline Prior treatment, $\mathrm{n}(\%)$ & $10(37)$ \\
\hline Antiplatelets & $7(26)$ \\
\hline Anticoagulation & $13(48)$ \\
\hline Statins & $15(56)$ \\
\hline Antihypertensive drugs & $20(74)$ \\
\hline Occlusion site, $\mathrm{n}$ (\%) & $3(11)$ \\
\hline Middle cerebral artery - M1 & $2(7)$ \\
\hline Middle cerebral artery - M2 & $2(7)$ \\
\hline Intracranial carotid artery & \\
\hline Posterior circulation & \\
\hline
\end{tabular}


Table 1. Continuation.

\begin{tabular}{|c|c|}
\hline Previous IV-tPA, n (\%) & $16(59)$ \\
\hline Window to needle time - minutes, mean $( \pm S D)$ & $182( \pm 53)$ \\
\hline Door to needle time - minutes, mean ( \pm SD) & $42( \pm 16)$ \\
\hline $\begin{array}{l}\text { Symptoms onset to groin puncture time - } \\
\text { minutes, mean }( \pm S D)\end{array}$ & $258( \pm 134)$ \\
\hline $\begin{array}{l}\text { Symptoms onset to recanalization time - } \\
\text { minutes, mean }( \pm S D)\end{array}$ & $289( \pm 153)$ \\
\hline Door to groin puncture time - minutes, mean $( \pm S D)$ & $104( \pm 50)$ \\
\hline Solitaire Stent Retriever ${ }^{\mathrm{TM}}$, n (\%) & $18(67)$ \\
\hline Trevo Stent Retriever ${ }^{T M}$, n (\%) mTICl 2b/3, n (\%) & $9(33) 21(78)$ \\
\hline Symptomatic hemorrhagic transformation, n (\%) & $2(8)$ \\
\hline \multicolumn{2}{|l|}{ Stroke etiology, n (\%) } \\
\hline Cardioembolic & $14(52)$ \\
\hline $\begin{array}{l}\text { Other causes (arterial dissection, prothrombotic } \\
\text { disease, post-procedural) }\end{array}$ & $7(26)$ \\
\hline Undetermined: Negative studies & $4(15)$ \\
\hline Undetermined:Two etiologies & $2(7)$ \\
\hline Pneumonia, n (\%) & $12(44)$ \\
\hline Days of hospitalization, mean \pm SD & $13( \pm 7)$ \\
\hline In-hospital mortality, n (\%) & $3(11)$ \\
\hline
\end{tabular}

IQR: interquartile range; $\mathrm{mTICl}$ : modified Thrombolysis in Cerebral Infarction scale; SD: standard deviation;TIA: transient ischemic attack. Continuous data are presented as the means \pm standard deviation; categorical data are given as the counts (percentage).
In a comparative analysis between patients with proximal occlusions (intracranial carotid artery and middle cerebral artery at $\mathrm{M} 1$ level) and distal occlusions (middle cerebral artery at M2 level or posterior circulation), the only statistically significant difference was the younger age in patients with distal occlusions ( $51 \pm 15$ vs. $71 \pm 12$; $\mathrm{p}=0.003$ ). There were four times more cases of left MCA - M1 occlusions than right MCA - M1 occlusions.

We also performed a comparative analysis between patients who did and did not receive IV-tPA before the MT. No statistically significant differences were found in relation to demographic data, site of occlusion, treatment times, or stroke etiology. The group that did not receive IV-tPA had a tendency for better median NIHSS at three months (4.5 vs 10), but without reaching statistical significances.

At the time of discharge, 14 patients received anticoagulation (52\%), nine antiaggregation (33\%), and, in four cases (15\%), a combined treatment (anticoagulation plus previous indication of antiaggregation). All subjects were prescribed statins and 55\%, antihypertensive drugs. Symptomatic hemorrhagic transformation occurred in 2 patients (8\%) without changes in mortality rates.

At 90 days of follow-up, the median NIHSS was 5 (IQR 3, $15)$ and the favorable outcome $(\mathrm{mRS} \leq 2)$ was achieved in 10 cases (37\%) (Figure 1). Mortality rate at 90 days was $11 \%$.

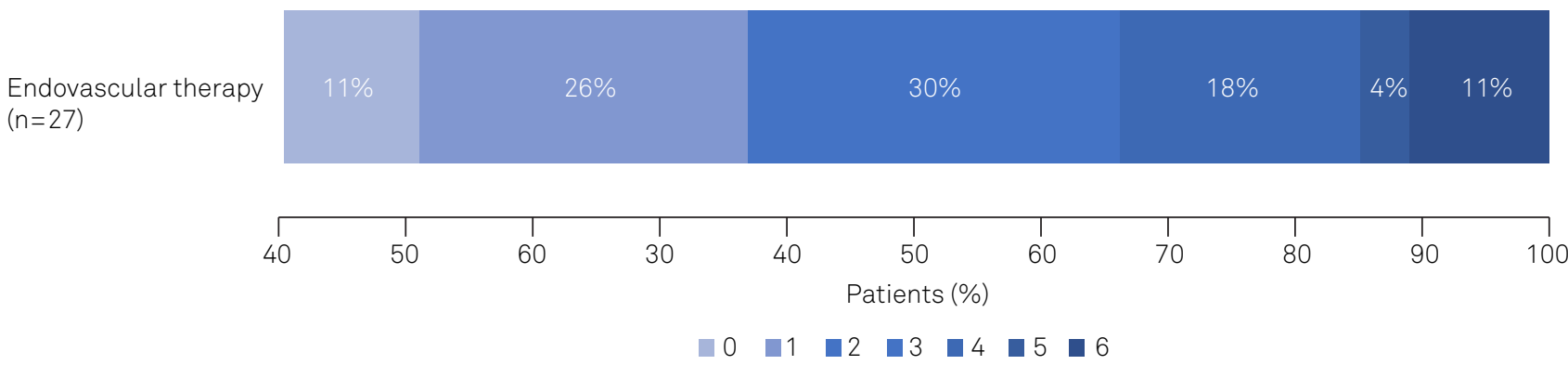

Figure 1. Modified Rankin Scale at 3 months.

Table 2. Case series of endovascular treatment in South America.

\begin{tabular}{|c|c|c|c|c|c|c|c|}
\hline Country & Year & $\begin{array}{c}\text { Patients, } \\
n\end{array}$ & $\begin{array}{c}\text { Recanalization } \\
(\mathrm{mTICl}=2 \mathrm{~b} / 3), \\
\mathrm{n}(\%)\end{array}$ & $\begin{array}{c}\mathrm{mRS}-2 \text { at } 3 \\
\text { months, } \\
\mathrm{n}(\%)\end{array}$ & $\begin{array}{c}\text { Symptomatic } \\
\text { hemorrhagic } \\
\text { transformation, } \\
\mathrm{n}(\%)\end{array}$ & $\begin{array}{c}\text { Mortality at } 3 \\
\text { months, } \\
\text { n (\%) }\end{array}$ & $\begin{array}{l}\text { NIHSS at } \\
\text { admission, } \\
\text { mean (IQR) }\end{array}$ \\
\hline Brazil $^{16}$ & 2016 & 161 & $120(76)$ & $58(36)$ & $11(7)$ & $37(23)$ & $19(15,24)$ \\
\hline Brazil17 & 2016 & 31 & $22(71)$ & $17(55)$ & $10(12)$ & $7(23)$ & $19(17,24)$ \\
\hline Colombia $^{18}$ & 2016 & 10 & $7(70)$ & $7(70)$ & $2(20)$ & $2(20)$ & $17.5(17,22)$ \\
\hline Argentina $^{19}$ & 2016 & 11 & $8(73)$ & $3(28)$ & $5(45)$ & $3(27)$ & $19(13,25)$ \\
\hline $\begin{array}{l}\text { Argentina } \\
\text { (present report) }\end{array}$ & 2018 & 27 & $21(78)$ & $10(37)$ & $2(8)$ & $3(11)$ & $20(14,24)$ \\
\hline
\end{tabular}

mRS: modified Rankin Scale; mTICl: modified Thrombolysis in Cerebral Infarction; IQR: interquartile range. 


\section{DISCUSSION}

We report the use of MT in 3\% of patients admitted to our Stroke Unit with diagnosis of acute ischemic stroke. We obtained a high rate of recanalization, performing the procedure within the recommended times, with a low number of serious complications and good functional recovery at three months.

Our center is a non-profit clinical and research Neurology and Neurosurgical institution, with 113 inpatient beds. We have a Vascular Neurology section since 1996, with eight vascular neurologists in the staff and two fellows. We incorporated the fibrinolytic treatment in 1997. In 2012, we opened our Stroke Unit with five beds and written admission criteria. We have been performing endovascular acute stroke treatments since 2015. We have a neurologist on call 24 hours a day. Our catchment area is variable. Most patients live in the city of Buenos Aires and its suburbs (population=14.8 million). We receive some patients with EMS pre-notification, and many come to our emergency room using their own transportation.

The most frequent occlusion site was the M1 segment of MCA, and we found four times more cases of left MCA than right MCA. This result is likely caused by chance, although we cannot rule out a bias introduced by the presence of hemineglect in right MCA strokes, causing delay in consultation. Cardioembolic stroke was the most frequent etiology in these patients. A combined treatment with IV-tPA was done in approximately half of the cases, without affecting time to MT.

In comparison to published data from clinical trials, our population had higher NIHSS score at admission, similar times from stroke to groin puncture, similar recanalization rates and equal good functional outcome at three months ${ }^{15}$.

In Latin America, thrombolysis for patients with acute ischemic stroke is available in all countries, but only for a relatively small proportion of patients (usually<1\%). An even smaller proportion of eligible patients received thrombectomy ${ }^{16}$.

Only few case series of the use of MT for acute ischemic stroke are reported in South America. Two studies from Brazil reported an acceptable efficacy and good safety results ${ }^{17,18}$. Another study from Colombia found high impacts in functional independency at three months, without increase in mortality ${ }^{19}$. Finally, a case series from another center in Argentina showed a good recanalization rate $(73 \%)$ with a three-month mortality of $27.3 \%^{20}$ (Table 2). With the establishment of endovascular treatment as a standard of care and its increased use, it is important to encourage institutional initiatives to monitor and improve procedural metrics of safety and efficacy ${ }^{21}$.

In the Declaration of Gramado, stroke experts from 13 Latin American countries agreed on the need to increase the development of stroke units and to implement evidence-based treatments of thrombolysis as a first step, and thrombectomy in comprehensive centers as the next step ${ }^{16}$. Our report adds to these data, suggesting the feasibility of the implementation of MT protocols in Latin America.

In conclusion, MT is feasible in our environment. The use of strict protocols and the training of a multidisciplinary team is a key factor in the identification of patients who can benefit from this treatment.

\section{ACKNOWLEDGMENTS}

We thank Drs. Carlos Miranda and Virginia González Quaranta for their participation in most endovascular procedures.

\section{References}

1. Feigin VL, Norrving B, Mensah GA. Global Burden of Stroke. Circ Res. 2017 Feb;120(3):439-48. https://doi.org/10.1161/ CIRCRESAHA.116.308413

2. Natalidad y mortalidad. Síntesis estadística. Dirección de estadísticas e información en Salud. Ministerio de Salud de la Nación. Available from: http://www.deis.msal.gov.ar/wp-content/ uploads/2016/05/Sintesis-estadistica-Nro1.pdf

3. Gómez-Schneider MM, Pujol-Lereis VA, Dossi D, Hawkes MA, Alet M, Rodriguez-Lucci F, et al. Prevalence of stroke in Argentina: A population-based Epidemiological Study (EstEPA). Stroke. 2018 Jan;49(Supl. 1):AWP196. https://doi.org/10.1161/str.49.suppl_1. WP196

4. Dossi D, Pujol-Lereis V, Gómez-Schneider M, Gonzalez G, Hawkes MA, Rodriguez Lucci F, et al. Stroke Mortality in Argentina. A populationbased Epidemiological Study, EstEPA. Stroke. 2018;49(Supl. 1):ATP197. https://doi.org/10.1161/str.49.suppl_1.TP197

5. The National Institute of Neurological Disorders and Stroke rtPA Stroke Study Group. Tissue plasminogen activator for acute ischemic stroke. N Engl J Med. 1995 Dec;333(24):1581-8. https://doi. org/10.1056/NEJM199512143332401
6. Goyal M, Demchuk AM, Menon BK, Eesa M, Rempel JL, Thornton J, et al. Randomized assessment of rapid endovascular treatment of ischemic stroke. N Engl J Med. 2015 Mar;372:1019-30. https://doi. org/10.1056/NEJMoa1414905

7. Berkhemer O, Fransen P, Beumer D, van den Berg LA, Lingsma HF, Yoo AJ, et al. A randomized trial of intraarterial treatment for acute ischemic stroke. N Engl J Med. 2015 Jan;372:11-20. https://doi. org/10.1056/NEJMoa1411587

8. Campbell BCV, Mitchell PJ, Kleinig TJ, Dewey HM, Churilov L, Yassi $\mathrm{N}$, el at. Endovascular therapy for ischemic stroke with perfusionimaging selection. N Engl J Med. 2015 Mar;372:1009-18. https://doi. org/10.1056/NEJMoa1414792

9. Saver JL, Goyal M, Bonafe A, Diener HC, Levy El, Pereira VM, et al. Stent-retriever thrombectomy after intravenous t-PA vs. t-PA alone in stroke. N Engl J Med. 2015 Jun;372(24):2285-95. https://doi. org/10.1056/NEJMoa1415061

10. Jovin TG, Chamorro A, Cobo E, de Miquel MA, Molina CA, Rovira $A$, et al. Thrombectomy within 8 hours after symptom onset in ischemic stroke. N Engl J Med Jun. 2015;372:2296-306. https://doi. org/10.1056/NEJMoa1503780 
11. Nogueira R, Jadhav A, Haussen D, Bonafe A, Budzik RF, Bhuva P, et al. DAWN trial investigators. Thrombectomy 6 to 24 hours after stroke with a mismatch between deficit and infarct. N Engl J Med. 2018 Jan;378:11-21. https://doi.org/10.1056/NEJMoa1706442

12. Albers G, Marks M, Kemp S, Christensen S, Tsai JP, Ortega-Gutierrez S, et al. DEFUSE 3 Investigators. Thrombectomy for Stroke at 6 to 16 Hours with Selection by Perfusion Imaging. N Engl J Med. 2018;378:708-18. https://doi.org/10.1056/NEJMoa1713973

13. National Institute of Neurological Disorders and Stroke. NIH Stroke Scale. Available from: https://www.ninds.nih.gov/doctors/NIH Stroke Scale.pdf

14. Higashida RT, Furlan AJ, Roberts H, Tomsick T, Connors B, Barr J, et al. Trial design and reporting standards for intra-arterial cerebral thrombolysis for acute ischemic stroke. Stroke. 2003;34(8):109-37. https://doi.org/10.1161/01.STR.0000082721.62796.09

15. Goyal M, Menon BK, van Zwam WH, Dippel DJW, Mitchell PJ, Demchuk AM, et al. Endovascular thrombectomy after large-vessel ischaemic stroke: A meta-analysis of individual patient data from five randomised trials. Lancet. 2016 Apr;387(10029):1723-31. https://doi. org/10.1016/S0140-6736(16)00163-X

16. Ouriques Martins SC, Sacks C, Hacke W, Brainin M, de Assis

Figueiredo F, Marques Pontes-Neto O, et al. Priorities to reduce the burden of stroke in Latin American countries. Lancet Neurol. 2019 Jul;18(7):674-83. https://doi.org/10.1016/S1474-4422(19)30068-7
17. Nakiri G, Castro-Alfonso L, Monsignore L, Dias FA, Alessio-Alves FF, Fabio SR, et al. Experience on Mechanical Thrombectomy for Acute Stroke Treatment in a Brazilian University Hospital. J Stroke Cerebrovasc Dis. 2017;26(3):532-7. https://doi.org/10.1016/j. jstrokecerebrovasdis.2016.11.128

18. Cabral N, Conforto A, Magalhaes P, Longo LL, Moro CHC, Appel H, et al. Intravenous rtPA versus mechanical thrombectomy in acute ischemic stroke: A historical cohort in Joinville, Brazil. eNeurologicalSci. 2016 Dec;5:1-6. https://doi.org/10.1016/j.ensci.2016.04.002

19. Muñoz J, Rivillas J, González Jaramillo N. Trombectomía mecánica en pacientes con ataque cerebrovascular isquémico: serie de casos en un centro de referencia colombiano. Acta Neurol Colomb. 2017;33(2):68-73. http://dx.doi. org/10.22379/24224022136

20. Colla Machado PE, Pigretti SG, Balian NR, Luzzi AA, Rabellino JM, Peralta OA, et al. Trombectomía mecánica en el tratamiento del accidente cerebrovascular isquémico: experiencia de un centro de alta complejidad en Argentina. Neurol Arg. 2016 Jul/Sep;8(3):145-51. https://doi.org/10.1016/j.neuarg.2016.02.011

21. Pontes-Neto OM, Cougo P, Martins SC, Abud DG, Nogueira RG, Miranda M, et al. Brazilian guidelines for endovascular treatment of patients with acute ischemic stroke. Arq Neuropsiquiatr. 2017 Jan;75(1):50-6. http://dx.doi.org/10.1590/0004-282x20160174 